\title{
The Effectiveness of a Collaborative Academic Supervision Model of Principal and Senior Teachers in Improving Junior Teachers' Academic Supervision Competence
}

\author{
Suwardi, Suyatno ${ }^{*}$, Suharsimi Arikunto \\ Department of Education Management, Universitas Ahmad Dahlan, Indonesia
}

Received May 27, 2020; Revised September 27, 2020; Accepted November 19, 2020

\begin{abstract}
Cite This Paper in the following Citation Styles
(a): [1] Suwardi, Suyatno, Suharsimi Arikunto , "The Effectiveness of a Collaborative Academic Supervision Model of Principal and Senior Teachers in Improving Junior Teachers' Academic Supervision Competence," Universal Journal of Educational Research, Vol. 8, No. 12A, pp. 7218 - 7226, 2020. DOI: 10.13189/ujer.2020.082503.
\end{abstract}

(b): Suwardi, Suyatno, Suharsimi Arikunto (2020). The Effectiveness of a Collaborative Academic Supervision Model of Principal and Senior Teachers in Improving Junior Teachers' Academic Supervision Competence. Universal Journal of Educational Research, 8(12A), 7218 - 7226. DOI: 10.13189/ujer.2020.082503.

Copyright $@ 2020$ by authors, all rights reserved. Authors agree that this article remains permanently open access under the terms of the Creative Commons Attribution License 4.0 International License

\begin{abstract}
Academic supervision is one of several activities carried out to ensure the quality of a teaching process in a classroom. However, the implementation of academic supervision faces some problems, such as the principal's and teachers' lack of competencies. The study aims to examine the effectiveness of the collaborative academic supervision model of a principal and senior teacher to improve teachers' academic supervision competence. The collaboration includes several activities, such as training and practice of academic supervision. The research belongs to experimental research with a pre-experimental design using one group pretest-posttest design. The data were taken using a questionnaire, observation, and a series of tests. They were analyzed using validity and reliability tests, as well as the descriptive statistic technique. The results show that the collaborative supervision model improves the junior teachers' academic supervision competence. It is evident in the higher score obtained in the posttest, compared to the pretest. The mean score posttest is 82.50, which increases significantly from the pretest mean score, 59.00. The findings prove that the collaboration between principal and senior teachers in conducting academic supervision helps the junior teachers to improve their competence. The research recommended the necessity of collaborative supervision between the principal and the senior teachers to enhance academic
\end{abstract}

supervisory competencies.

Keywords Collaboration, Academic Supervision, Principal, Senior Teachers

\section{Introduction}

Academic supervision is an activity conducted to monitor the teachers' performance in the teaching process, starting from planning the lesson, teaching, and evaluating the implementation. Academic supervision is carried out by a principal and a supervisor within the school area on a regular basis. Hay, Jay, and Clements (2011) explain that academic supervision is an activity conducted by teachers to ensure the learning quality. Meanwhile, Supardi (2013) defines supervision as the service to help, encourage, assist, and guide the teachers to increase their ability and skills in performing the tasks. Supervision activities in education are necessary to improve the learning process and the learning outcomes (Leniwati \& Arafat, 2017).

Supervision as a series of activities of assisting teachers in developing their abilities in managing the teaching and learning process to achieve the learning objectives (Glikman in Bafadal, 2007) defines. Previous studies 
(Zulfikar, 2017; Suwartini, 2017; Akhmad et al., 2014) show that the target of academic supervision is the teachers' ability to manage the classroom, such as planning, implementing, and evaluating the students' learning outcome. Bernard \& Goodyear in Moyer (2011) defines supervision as a continuous evaluative intervention carried out by the senior members of a profession to the junior members of the same professions, improving the professional capabilities of the juniors, to monitor the services provided, and to select those who will take the profession. Ambarita (2014) and Behlol (2011) mention that the basic function of supervision is to help teachers develop their ability to manage the teaching process.

The facts showed that the academic supervision performed by the principal and the supervisors was not effective. Consequently, it failed to ensure the learning quality in schools. Two factors caused the ineffectiveness. The first was the inadequate number of the supervisors and principals, which made the supervisory activities a mere formality. Second is less systematic and planned preparation for the supervisor candidates to help the principals and the supervisors. The school can overcome the problem by empowering the senior teachers, especially by collaborating with the relevant principals (Yunus, 2010).

Research about academic supervision is abundant, both the micro and macro scale. For example, Shahzadi (2014) reveals a relation between supervision conducted by a principal and the teachers' performance. Similar results were found by Hijriyah (2011), who researched the principals in Bantul. She found that the academic supervision in Bantul runs less optimally because the principals have various duties outside the schools. Besides, Fikriyah (2018) stated that a principal, as an academic supervisor, should know the learning methods and facilities needed for the teaching and learning process. Akhmad (2014) argues that the supervision carried out by a supervisor and a principal has not been adequate to maintain the teachers' professionalism. The supervision is well planned in a program but has not been implemented accordingly. In practice, the principal delegated the teachers to supervise other teachers. Meanwhile, Yunus (2010) found that most principals ignore their duties as an educational supervisor, yet it concerns school management. Consequently, they spend less than a third of their time to do the supervision.

Based on the previous studies, it can be concluded that they have not focused on the collaborative academic supervision model between a principal and teachers. For example, Rahabav (2016) focused the study on the effectiveness of academic supervision by a supervisor to the teachers' performance. Meanwhile, Saleh (2017) examined the development of an academic supervision program through Teacher Work Group forum empowerment. Working in a group allows teachers to train their ability in packaging the teaching process even if it is without the supervision of the principal and supervisor. Others conducted by Renata (2018) and Karnati (2019) focused on a principal's supervision in improving the teachers' performance. We can see that they emphasize on single supervision, either by a principal or by a supervisor.

Conversely, the present study examines the effectiveness of collaborative academic supervision between a principal and teachers. The study is necessary to conduct because the collaboration model is the real manifestation of preparing an academic supervisor to solve the problems in the field, such as the less significant role of the supervision carried out by the principal and/or the supervisor. If a school has an academic supervisor other than the principal and the supervisor, it will be the teachers having the capability. Therefore, the result of the research can be a recommendation for schools or educational board to overcome the problem faced in relation to the implementation of academic supervision.

\section{Literature Review}

\section{The Urgency of Academic Supervision in Improving the Learning Quality}

Academic supervision is a set of activities to assist teachers in developing their ability to manage the teaching process that allows them to achieve the learning objectives. According to Sujana (2011), academic supervision is assessing and guiding the teachers to improve the quality of the teaching process, improving the learners' competence. Adewale (2014) suggested that it can enhance the learning quality, maintain good relationships among teachers, and provide corrective feedback. An eligible supervisor can achieve appropriate supervision. A supervisor is an individual involving in monitoring or supervising the instructions given to the subordinates to provide continuous guidance, supports, and evaluation to improve the quality of the teaching and learning process.

According to Dodd in Daryanto (2015), academic supervisions have several principles. They are (1) practical (easy to do according to the school condition); (2) systematic (developed following the supervision programs); (3) objective (inputs suitable with the instruments); (4) realistic (real-time condition); (5) anticipative (ability to anticipate any problem): (6) constructive (creative and innovative teachers in developing the learning process); (7) cooperative (good cooperation between supervisor and teachers); (8) familiarity (teaching, loving, and caring in developing the learning); (9) democracy (less dominating supervision); (10) active (active participation of teachers and supervisor); (11) humanistic (ability to create harmonious, open, honest, steady, patient, enthusiastic, and humorous relationship); (12) sustainable (well-planned and continuous supervision by the principal); (13) integrated (integration with the 
education programs); and (14) comprehensive (fulfilling the objectives of academic supervision).

Several academic supervision techniques are developed to improve teachers' competence. Daryanto (2015) mentioned two common techniques to use. First is individual supervision, consisting of four ways: class visits, class observation, individual meetings, and self-assessment. Second is group supervision, of which the program is intended for two people or more. In this context, the teachers identified as having similar needs, problems, and weaknesses, are grouped and supervised accordingly. Several types of group supervision used are teaching demonstration, teachers' meetings, workshops, seminars, and working groups.

The follow-up of supervision results is carried out after the observation. The feedback session is necessary to develop the teachers' competence. A supervisor conducting the follow-up session follows the Permendikbud No 65 of 2013 on Process Standard, regulating two matters. First is empowerment and rewards for teachers who achieve the required standards or surpass the standards. Second is assigning teachers to attend continuous professional development. The results of the supervision need to be followed-up to increase the teachers' professionalism. The follow-up begins by analyzing the teachers' weaknesses and strengths or instruments. The results and the supervisor's notes are used to develop the teachers' competence in performing the teaching process, allowing them to improve their professionalism. Besides, the feedback can create harmonious communication, thereby encouraging teachers to increase their performance through assisting activities. Sudarat (2015) proposes that supervision is translated as monitoring. Indeed, it has a specific meaning, which is to help and participate in the attempts to improve the quality, to maintain a good teaching and learning environment, thereby allowing the teachers to use their creativity and internalize their responsibilities in accomplishing the tasks. Saani (2013) found that supervision over the teachers positively influences the teachers' performance.

\section{Model of Collaborative Academic Supervision of Principal and Senior Teachers}

Wahjosimidjo (2015) explained that a principal is an operational staff assigned to lead a school, where there is an interaction among teachers giving the lessons and learners receiving the lesson. Further, Mulyasa (2014) mentioned that the head of a madrasah is the motor and policymaker of a madrasah, who will determine the goals of education.

In a Beginner Teacher Induction Program, Daryanto (2015) defined a senior teacher as a counselor. It is an experienced teacher assigned by the principal/madrasah based on professionalism and communication skills. To be a counselor, a teacher should have several capabilities and characteristics. A counselor should be (a) competent as a professional teacher; (b) able to work with others; (c) good at communication skills; (d) able to analyze and provide feedback for teaching and learning process or counseling and guidance; and (e) experienced in teaching at the same grade and the same subject as beginner level. In addition, the teacher should have at least a five-year teaching experience and hold at least the position of a novice teacher.

The research applies collaboration between a principal and teachers in understanding the concept of academic supervision. Teachers selected as the subject of the research are senior teachers considered eligible to be an academic supervisor. Supervision as a continuous evaluative intervention carried out by a senior member of a profession to the junior members of the same profession. It is to improve their professionalism and to monitor the services provided. The collaboration will create a good learning environment, allowing them to share the same perception of academic supervision. The program begins with the training and ends in the implementation of academic supervision. Collaboration means a process, a continuous interaction among people. Meanwhile, Lai (2011) explains that collaboration is a joint involvement in a coordinated effort to solve a problem. Collaborative interaction is signified by establishing a collective goal, building asymmetrical structure with high-level negotiation through interactivity and dependence. In her book Collaborative Learning Technique, Barkley (2014) suggested that practicing collaborative learning means working in pairs or in a small group to achieve a collective learning objective. Collaborative learning refers to learning in a group instead of individually.

\section{Conceptual Framework}

Principal refers to the head of the school, supervisor, head of the educational unit, teaching program executing committee, teachers, and curriculum managers (Nakpodia, 2011). In the induction program of novice teachers, the senior teachers serve as a consultant. It is a professional teacher with adequate teaching experience and is assigned by the principal based on their professionalism and communication skills (Daryanto, 2015). In the collaborative model, the principal and the senior teachers work together in supervising the junior teachers. The activities range from planning, implementing, and follow-up. The collaboration allows the teachers to learn from the mentors. In other words, they are learning by doing because the senior teachers directly practice academic supervision. It is expected to be the solution to the problems in the supervisory programs at school. The theoretical framework of the research is presented in figure I. 


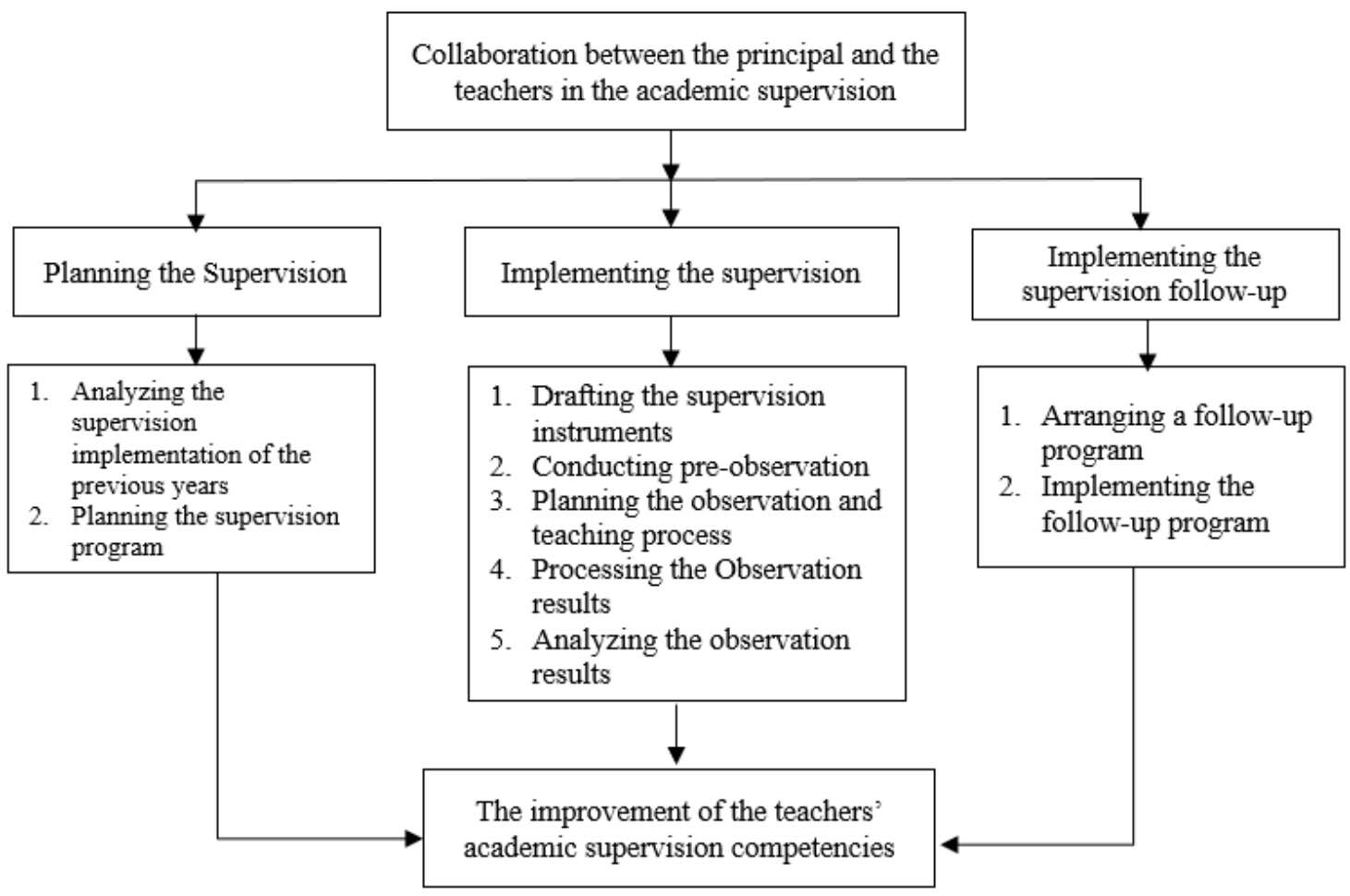

Figure 1. Conceptual framework

\section{Research Hypothesis}

Based on the relevant literature, the hypotheses of the research are as follows:

H0: The collaborative academic supervision model between principal and teachers are not effective in improving the teachers' academic supervision competencies.

H1: The collaborative academic supervision model between principals and teachers effectively improves the teachers' academic supervision competencies.

\section{Research Methods}

\section{Research Design}

The research belongs to the experiment methods with pre-experimental design, one group pretest-posttest. Arikunto (2010: 124) stated that one group pretest-posttest design is an activity where the respondents are given pretest before the treatment and given posttest after the treatment. Sugiyono (2017) proposes that one group pretest and posttest design is carried out by measuring at the beginning (pretest) before the treatment and performing another at the end (posttest). A pretest is intended to know the participants (teachers) in understanding the concept of academic supervision. After the results are gained, they were treated using collaborative supervision. The collaboration is between the principal and the teachers. The measurement of the posttest is to know the ability of the participants (teachers) in academic supervision.

\section{Participants}

The population of the research consists of the principals and the teachers of two elementary schools (SD Unggulan Aisyiyah Bantul and SD Muhammadiyah Bantul Kota). The subjects were selected using a purposive sampling technique, the key informant (two principals), and two senior teachers of each school. The demography of the research subject can be seen in table 1 .

Table 1. Demography of the Research Respondents

\begin{tabular}{|c|c|c|c|c|c|c|c|}
\hline No & Institution & Principal & Working experience & Gender & Teacher & Teaching experience & Gender \\
\hline 1 & $\begin{array}{c}\text { SD Unggulan } \\
\text { Aisyiyah Bantul }\end{array}$ & $\mathrm{Sw}$ & 5 & Male & $\mathrm{Sk}$ & 9 & Male \\
\cline { 5 - 9 } & & $\mathrm{N}$ & $\mathrm{Pw}$ & 12 & Female \\
\hline
\end{tabular}


The Effectiveness of a Collaborative Academic Supervision Model of

Principal and Senior Teachers in Improving Junior Teachers' Academic Supervision Competence

Table 2. Results of Validity and Reliability Test of the Research Instrument

\begin{tabular}{|c|c|c|c|c|}
\hline Items & $\begin{array}{c}\text { Corrected Item-Total } \\
\text { Correlation } \\
\end{array}$ & $\begin{array}{c}\text { VALID }=r-\text { count }>\text { r-table } \\
\text { R table } \mathrm{n}-2=0,306\end{array}$ & $\begin{array}{c}\text { Cronbach's Alpha if Item } \\
\text { Deleted }\end{array}$ & Reliable R count $>0,5$ \\
\hline Item 1 & .436 & Valid & .893 & reliable \\
\hline Item 2 & .411 & Valid & .893 & reliable \\
\hline Item 3 & .502 & Valid & .892 & reliable \\
\hline Item 4 & .329 & Valid & .895 & reliable \\
\hline Item 5 & .502 & Valid & .891 & reliable \\
\hline Item 6 & .330 & Valid & .895 & reliable \\
\hline Item 7 & .531 & Valid & .891 & reliable \\
\hline Item 8 & .408 & Valid & .893 & reliable \\
\hline Item 9 & .396 & Valid & .894 & reliable \\
\hline Item 10 & .513 & Valid & .891 & reliable \\
\hline Item 11 & .534 & Valid & .891 & reliable \\
\hline Item 12 & .403 & Valid & .893 & reliable \\
\hline Item 13 & .329 & Valid & .895 & reliable \\
\hline Item 14 & .382 & Valid & .894 & reliable \\
\hline Item 15 & .468 & Valid & .892 & reliable \\
\hline Item 16 & .531 & Valid & .891 & reliable \\
\hline Item 17 & .355 & Valid & .894 & reliable \\
\hline Item 18 & .597 & Valid & .890 & reliable \\
\hline Item 19 & .371 & Valid & .894 & reliable \\
\hline Item 20 & .436 & Valid & .893 & reliable \\
\hline Item 21 & .542 & Valid & .891 & reliable \\
\hline Item 22 & .372 & Valid & .894 & reliable \\
\hline Item 23 & .500 & Valid & .892 & reliable \\
\hline Item 24 & .531 & Valid & .891 & reliable \\
\hline Item 25 & .350 & Valid & .894 & reliable \\
\hline Item 26 & .464 & Valid & .892 & reliable \\
\hline Item 27 & .521 & Valid & .891 & reliable \\
\hline Item 28 & .382 & Valid & .894 & reliable \\
\hline Item 29 & .535 & Valid & .891 & reliable \\
\hline Item 30 & .429 & Valid & .893 & reliable \\
\hline
\end{tabular}

\section{Data Collecting Technique and Instruments}

Darmawan (2013) explained that the data collecting technique is a set of ways taken in research, while instrument means the tools used by a researcher in collecting the data. The technique used in this research is questionnaire, observation, documentation, and tests. Meanwhile, the instruments are questionnaires, observation sheets, documentation guidelines, and projection test items. The instruments are validated by two experts and considered appropriate to use.

The validity was tested using a product-moment test, resulting in 30 valid items because r-count is higher than r-table (0.306). Meanwhile, the reliability of the items was tested using the Alpha test, and it was found that the 30 items were reliable because the r-count is higher than the r-table (0.5). After the items for the pretest and posttest passed the reliability and validity test, they can be used to measure the ability of the participants of the study. The validity and reliability test results are presented in Table 2.

\section{Data Analyzing Technique}

Table 3. Assessment Scale

\begin{tabular}{|c|c|c|}
\hline No & Range & Category \\
\hline 1 & $81-100$ & Very high \\
\hline 2 & $61-80$ & High \\
\hline 3 & $41-60$ & Medium \\
\hline 4 & $21-40$ & Low \\
\hline 5 & $1-20$ & Very low \\
\hline
\end{tabular}


The data used for the study are the results of the tests. As mentioned previously, the validity test was conducted using product moment with $r$ table of 0.306 , while the reliability was tested using the alpha test with $\mathrm{r}$ table 0.5 . The hypothesis was tested by calculating the mean of the pretest and posttest. The data were analyzed descriptively to measure the effectiveness of the research. The study aims to know the collaborative model carried out by the principal and the senior teachers in improving the junior teachers' academic supervision competence. In the research, the model's effectiveness is determined by the competence achieved by the teachers after attending a training (posttest), compared to the competence before the training (pretest).
Since the number of subjects is small, the mean is calculated manually (Arikunto, 2010) with the category in table 3.

\section{Findings}

\section{The Implementation of the Academic Supervision Model by the Principal and the Teachers}

The implementation of the academic supervision model in this research was carried out in three steps: In- 1 , On, and In-2. The syntax of the steps is explained in table 4.

Table 4. Syntax of Collaboration academic supervision model

\begin{tabular}{|c|c|c|}
\hline Phase & Steps & Description of Activity \\
\hline \multirow[b]{5}{*}{ In-1 } & Orientation for the training & \multirow{5}{*}{$\begin{array}{l}\text { Before joining the training, the subjects were given a pretest to know their knowledge } \\
\text { about academic supervision. The next step is training. The principal assisted the } \\
\text { subjects in following the training guided by an expert. The training is to help the } \\
\text { subjects understand the concept of academic supervision. It begins by giving the } \\
\text { materials on the concept, such as the definition of academic supervision and } \\
\text { supervisor, the preparation of the academic supervision, implementation of academic } \\
\text { supervision, and follow-up of the academic supervision. The training employed } \\
\text { PowerPoint media and provided a module for the teacher. The activities include } \\
\text { question and answer sessions related to the topic, which is academic supervision. The } \\
\text { next step is the presentation of conducting academic supervision by a principal to the } \\
\text { teachers through a video. By observing the video, the participants obtain an ideal } \\
\text { illustration of conducting academic supervision. } \\
\text { The next step in training is a collaborative activity between the principal and the } \\
\text { teachers in practicing academic supervision. In the first activity, the principal and the } \\
\text { teachers collaborate in supervising the administrative step of preparing a Lesson Plan. } \\
\text { They discuss and assess the Lesson Plan following the concept of academic } \\
\text { supervision. The activity is continued by the second collaboration activity, observing } \\
\text { a video containing a teaching and learning process. The participants work together to } \\
\text { assess the video for all the aspects related to the learning process, starting from } \\
\text { opening the lesson, the main activity to closing the lesson. After that, the participants } \\
\text { discuss the observation of the Lesson Plan and the video with the speaker. }\end{array}$} \\
\hline & $\begin{array}{c}\text { Training for academic supervision by } \\
\text { a supervisor }\end{array}$ & \\
\hline & $\begin{array}{c}\text { Administrative supervision } \\
\text { Teaching supervision (observing a } \\
\text { video) }\end{array}$ & \\
\hline & Independent supervision training & \\
\hline & $\begin{array}{c}\text { Administrative supervision } \\
\text { Teaching supervision (observing a } \\
\text { video) }\end{array}$ & \\
\hline \multirow{3}{*}{ On } & Collaborative supervision practice & \multirow{3}{*}{$\begin{array}{l}\text { In implementing the academic supervision, the principal and the teachers collaborate } \\
\text { in planning the supervision for the lesson plan, the learning strategy, the learning } \\
\text { media, the learning resources, and the learning process. The supervision is continued } \\
\text { in the classroom. The principal and the teachers observe and assess the teaching } \\
\text { process performed by the junior teachers in the class. The observation ends with the } \\
\text { discussion about the teaching and learning process with the junior teachers. The } \\
\text { collaboration ensures that the principal and the teachers have the same perception } \\
\text { about the implementation of academic supervision. }\end{array}$} \\
\hline & $\begin{array}{l}\text { Administrative supervision } \\
\text { (collaborative) } \\
\text { Teaching supervision (collaborative) }\end{array}$ & \\
\hline & $\begin{array}{c}\text { Administrative supervision } \\
\text { (independent) } \\
\text { Teaching supervision (independent) }\end{array}$ & \\
\hline \multirow[b]{3}{*}{ In-2 } & $\begin{array}{r}\text { Presentation of th } \\
\text { result }\end{array}$ & \multirow{3}{*}{$\begin{array}{l}\text { The final activity in In-2 is divided into five. The principal and the teachers (1) collect } \\
\text { the data of the academic supervision to the junior teachers; (2) compare the results of } \\
\text { the first and second supervision; (3) write the report of the academic supervision to be } \\
\text { presented; (4) present the results of academic supervision; (5) take the posttest. } \\
\text { In training, the principal and the senior teachers work individually and collaboratively } \\
\text { to apply the concept of academic supervision to the junior teachers. During the } \\
\text { implementation, the participants collect the relevant data that will be useful for the } \\
\text { follow-up. Besides, the data can add the insight of the participant about academic } \\
\text { supervision. The training for the participants has two main steps: collaborative and } \\
\text { independent supervision. The collaborative supervision is conducted to improve the } \\
\text { principal's competence in preparing the teachers to be an academic supervisor. In the } \\
\text { stage, the principal and the teachers align their perception of academic supervision } \\
\text { before conducting individual supervision. }\end{array}$} \\
\hline & $\begin{array}{r}\text { Discussion of the } \\
\text { implemen }\end{array}$ & \\
\hline & Evaluation & \\
\hline
\end{tabular}




\section{The Effectiveness of the Academic Supervision Model}

The model's effectiveness was determined by comparing the mean score of the pretest and that of the posttest, presented in table 5 .

Table 5. Pretest and Posttest Results

\begin{tabular}{|c|c|c|c|c|}
\hline No & $\begin{array}{c}\text { Teacher's } \\
\text { initial name }\end{array}$ & School & $\begin{array}{l}\text { Pre } \\
\text { Test }\end{array}$ & $\begin{array}{l}\text { Post } \\
\text { Test }\end{array}$ \\
\hline 1 & Sk & $\begin{array}{c}\text { SD Unggulan } \\
\text { Aisyiyah }\end{array}$ & 66,00 & 84,00 \\
\hline 2 & $\mathrm{Pw}$ & $\begin{array}{c}\text { SD Unggulan } \\
\text { Aisyiyah } \\
\end{array}$ & 56,00 & 80,00 \\
\hline 3 & Ad & $\begin{array}{c}\text { SD Muh. Bantul } \\
\text { Kota }\end{array}$ & 54,00 & 84,00 \\
\hline 4 & $\mathrm{Pj}$ & $\begin{array}{c}\text { SD Muh. Bantul } \\
\text { Kota }\end{array}$ & 60,00 & 82,00 \\
\hline \multicolumn{3}{|c|}{ Total } & 236,00 & 355,00 \\
\hline \multicolumn{3}{|c|}{ Mean } & 59,00 & 88,75 \\
\hline
\end{tabular}

Table 5 shows that the teachers do not have the competence of a supervisor; it is evident in the score of the pretest of each: 66.00 ; 56.00; 54.00; and 60.00. The mean score is 59.00, categorized at a medium level. The mean score is below the minimum completeness criteria, which is 75.00. In other words, the teachers do not comprehensively understand the concept of academic supervision.

After attending the training, the score of each teacher increased, exceeding the completeness criteria, with the mean score 88.75 (very high category). Therefore, it can be concluded that the academic supervision model conducted by the principal and the senior teachers is effective in improving the junior teachers' competence in academic supervision. The improvement is presented in figure 2. The increase is the indicator of changes in the knowledge of the junior teachers prepared to be a supervisor about the concept of academic supervision. Improving the understanding of the research subjects is carried out through training, assisted by an expert. The teachers collaborate with the principal in performing academic supervision, allowing them to gain more experience and knowledge.

\section{Discussion}

The research aims to examine the hypothesis regarding the collaborative academic supervision program between the principals and senior teachers in improving the junior teachers' competence prepared to be a supervisor. The pretest and posttest show that the teachers make a significant improvement. Before the training, the mean score is 59.00. It increased after the training, which is 82.50 . The teachers are treated through training for conducting academic supervision with a collaborative program. The supporting data obtained in the research show a change in the attitude of the teachers, in that they gain more understanding of the concept of academic supervision.

In the collaboration, they build a professional talk guided by an expert. The interaction resulted in transferring knowledge one to another through a discussion, question and answer, feedback session, and testimony sharing about academic supervision. It is similar to the research conducted by Henricson and Nelson (2017), stating that giving suggestions is necessary for the interaction.

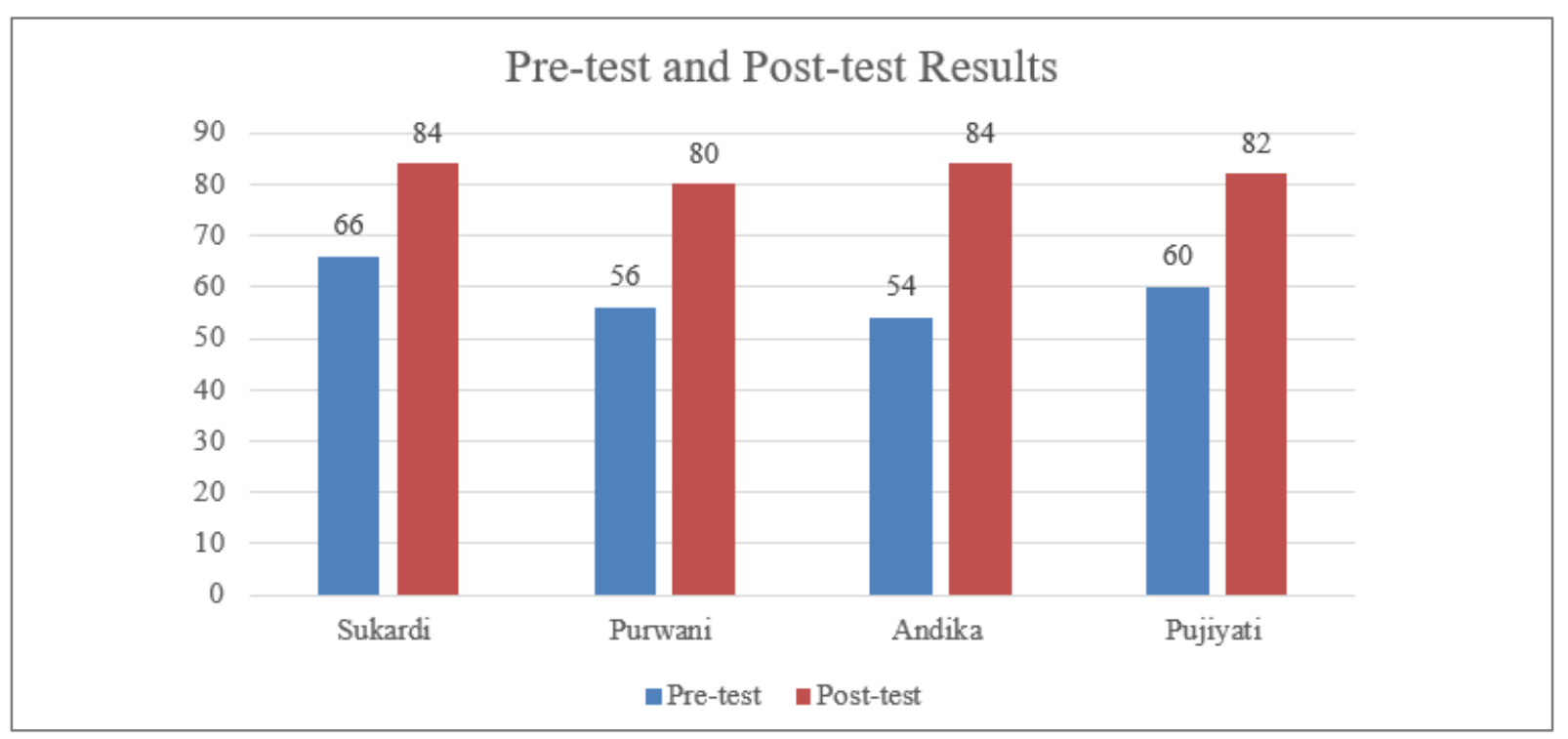

Figure 2. The score of pretest and post test results 
Adewale (2014) explains that academic supervision can improve the quality of the relationship among teachers and improve the existing condition. Hence, a supervisor is required to clearly understand the concept of supervision, such as the definition, the essence, the goals, and the advantages, to complete the tasks. A collaborative program between a principal and a teacher becomes an alternative to prepare an individual to be an academic supervisor. The program is proven successful, shown by a holistic increase in understanding of the research subjects.

The present study adds to the references of academic supervision implementation, which was previously less effective, as shown by previous studies (Yunus, 2010; Hijriyah, 2011; Sulthoni, 2014; Fikriyah, 2018). The results inform that almost all schools face a similar problem related to implementing academic supervision due to the limited time of the principal and the supervisor. The principal and the supervisor are assigned to do numerous managerial tasks; the number of supervisors in an area is limited, and the concept of academic supervision is not clearly understood. The treatment performed in the research has generated an academic supervisor ready to do all settings of the supervision: preparation, implementation, follow-up. A good supervisor having a comprehensive understanding can complete the task well, which assists another teacher in preparing the lesson, improving the motivation and skills in teaching, and improving the education quality of a school. Supervising is indeed a collective process without seeking each other's flaws, allowing the relevant parties to maintain the teaching quality. Similarly, Glanz (2012) states that supervision is a collaborative, continuous, judgeless, and developing process that encourages and reflects the teaching practice in the classroom.

\section{Conclusions}

It can be concluded that the program to prepare a supervisor candidate through collaborative training between a principal and the teachers is effective. Through the collaboration, the principal and the teachers shared perceptions about academic supervision. The supervisor, the principal, and the teachers prepared to be an academic supervisor shared their thoughts, discussed the concept, and transferred the knowledge, allowing them to develop equal competence to do supervision. The teachers prepared to be supervisors are expected to replace the principal's task as an academic supervisor. This way, the problems that occurred in schools related to the supervision can be overcome. The research recommended supervisory development to improve the teachers' supervisory competencies through a collaborative model. The program included three crucial stages: In 1, On, and In 2. In In-1, the teachers were given the orientation about the model, materials, and methods of the academic supervision program. The stage is also to build the same perception about the concept and materials of academic supervision. Stage On is the implementation of the collaborative academic supervision conducted by the teachers and the principal. The stage begins with collaborative activities continued by independent academic supervision. Stage In-2 was conducted through a discussion of the academic supervision results. At this stage, the participants, or the teachers, reflect their ideas about the implementation of the program. The collaborative model conducted in three stages was proven to improve the teachers' academic supervision competencies because they directly applied the concepts shared by the senior teachers and the principal.

\section{Acknowledgment}

The research is carried out with the financial support of the Directorate General of Research and Community Development of the Ministry of Education and Culture of the Republic of Indonesia in the form of a Master's Thesis Research Grant.

\section{REFERENCES}

[1] Adewale, O. S. (2014). Instructional Improvement of Secondary School Teachers Through Effective Academic Supervision by the Vice-Principals. Journal of Education and Human Development, 3(2), 607-617.

[2] Akhmad, S., Haryono, H., \& Fakhruddin, F. (2014). Pengembangan Model Supervisi Klinis Dengan Pendekatan Lesson Study Untuk Meningkatkan Kompetensi Profesional Guru Bahasa Inggris SMA Negeri Di Kabupaten Cilacap. Journal of Educational Research and Evaluation, 3(1).

[3] Ambarita, B., Siburian, P., \& Purba, S. (2014). Development of Academic Supervision Model which Based on Educational Management. International Journal of Sciences: Basic and Applied Research (IJSBAR), 18(1), 304-314.

[4] Arikunto, S. (2010). Prosedur Penelitian Suatu Pendekatan Praktik. Jakarta: Rineka Cipta.

[5] Bafadal, I. (2007). Supervisi Pengajaran Teori dan Aplikasi Dalam Membina Profesional Guru, Jakarta: Rineka Cipta.

[6] Barkley, E.E Cross, K.P., \& Major, C. H. (2014). Collaborative Learning Techniques. Bandung: Penerbit Nusa Media.

[7] Behlol, M. G. et al. (2011). Concept of Supervision and Supervisory Practices at Primary Level in Pakistan.International Education Studies4.4: 28-35.

[8] Darmawan. (2013). Metode Penelitian Kuantitatif. Bandung: Remaja Rosdakarya.

[9] Daryanto (2015). Supervisi Pembelajaran. Yogyakarta: Gava Media.

[10] Glanz, J. (2012). "Improving Instructional Quality in Jewish Day School and Yeshivot:" Best Practices Culled from 
Research and the field. New York, N.Y. 10033: Yeshiva University.

[11] Glickman, C.D., Gordon, S.P., and Ross-Gordon, J.M. (2007). Supervision and Instructional Leadership A Development Approach. Seventh Edition. Boston: Pearson.

[12] Hays, J., \& Clements, M. (2011). Supervision in work experience for learning programs. In Proceedings of the 17th World Conference on Cooperative and Work-Integrated Education (WACE).

[13] Henricson, S., \& Nelson, M. (2017). Giving and receiving advice in higher education. Comparing Sweden-Swedish and Finland-Swedish supervision meetings. Journal of Pragmatics, 109, 105-120. https://doi.org/10.1016/j.pragma .2016.12.013

[14] Hijriah, R. (2011). Supervisi Akademik Oleh Kepala Sekolah di Sekolah Dasar Se Kecamatan Bantul.

[15] Karnati, N. 2019. Academic Supervision To Improve The Competence Of Elementary School Teachers. Australasian Journal of Educational Technology, 35(1).

[16] Lai, E. R. (2011). Collaborations: A Literature Review. Pearson, p. 2.

[17] Leniwati, A. (2017). Implementasi Supervisi Akademik Kepala Sekolah untuk Meningkatkan Kinerja Guru. Palembang: Universitas PGRI

[18] Moyer, M. (2011). Effects of Non-Guidance Activities, Supervision, and Student-to-Counselor Ratios on School Counselor Burnout. Journal of School Counseling, 9(5), n5.

[19] Mulyasa, E. (2014). Manajemen Berbasis Sekolah. Bandung: Rosdakarya.

[20] Nakpodia, E.D. (2011). An Empirical Assessment of principal' supervision capacity. Journal of Education and Technology, Volume 1, Number 1, April 2011, pages 15-24.

[21] Rahabav, P. (2016). "The Effectiveness of Academic Supervision for Teachers." Journal of Education and Practice7.9: 47-55
[22] Renata, R., Wardiah, D., \& Kristiawan, M. (2018). The Influence of Headmaster's Supervision And Achievement Motivation On Effective Teachers. International Journal of Scientific \& Technology Research, 7(4).

[23] Saani, A.J., (2013). Influence of Compensation and Supervision on Private Basic School Teachers Work Performance in Ashaiman Municipality. International Journal of Business and Social Science Vol. 4 No. 17 Special Issue-December 2013.

[24] Shahzadi, I. \& Javed, F.K. (2014). Impact of Employee Motivation on Employee Performance. European Journal of Business and Management Vol.6, No.23, 2014.

[25] Sudjana. (2011). Supervisi Pendidikan: Konsep dan Aplikasinya Bagi Pengawas Sekolah. Bekasi: Binamitra Publishing.

[26] Sugiyono. (2017). Metode Penelitian Kuantitatif, Kualitatif, dan R\&D. Bandung: Alfabeta, CV.

[27] Supardi, (2013). Kinerja Guru. Jakarta: Raja Grafindo Perkasa.

[28] Suwartini, E. A. (2017). Supervisi Akademik Kepala Sekolah, Profesionalisme Guru dan Mutu Pendidikan. Jurnal Administrasi Pendidikan, 24(2), 62-70.

[29] Tyagi, R.S. (2010). School-based Instructional Supervision and the effectiveness professional of teachers project report, department of educational administration. NEUPA, New Delhi.

[30] Wahjosumidjo. (2011). Kepemimpinan Kepala Sekolah.PT. Raja Grafindo Persada, Jakarta.

[31] Yunus, Y. I., Yunus, J. N., \& Ishak, S. (2010). School principal's roles in teaching. Supervision in selected schools in Perak, Malaysia. Asian Journal of business and management sciences, 1(2), 50-55

[32] Zulfikar, Y., \& Ibrahim, S. (2017). Supervisi Akademik Oleh Kepala Sekolah Dalam Meningkatkan Kompetensi Profesional Guru SD Negeri 2 Calang Kabupaten Aceh Jaya. Jurnal Administrasi Pendidikan: Program Pascasarjana Unsyiah, 5(3). 